\title{
Morphology, secretion composition, and ecological aspects of stipular colleters in Rubiaceae species from tropical forest and savanna
}

\author{
Fernanda Tresmondi ${ }^{1}$ - Anselmo Nogueira ${ }^{2}$ - Elza Guimarães ${ }^{3}$. \\ Silvia Rodrigues Machado ${ }^{3}$
}

Received: 12 September 2015 / Accepted: 24 October 2015 /Published online: 19 November 2015

(C) Springer-Verlag Berlin Heidelberg 2015

\begin{abstract}
Colleters are secretory structures that produce and release mucilage or a mucilage-resin mixture protecting meristems and young structures against desiccation, herbivores, and pathogens. The secretions may vary in colleters of same or different types, indicating that the functionality of colleters may be more specific than previously thought. In this study, we compared 17 Rubiaceae species from savanna and forest environment focusing on colleter secretions and its ecological role. First, we evaluated the morphology, distribution, and histochemistry of stipular colleters using light and scanning electron microscopy. Additionally, we investigated the phenology, microclimate, and the proportion of damaged apices in the savanna and forest species. We recorded standard-type colleters, variable in distribution and size, in 14 of the 17 studied species. The secretion varied from predominantly hydrophilic, mixed to predominantly lipophilic. During the budding period, secretion covered the vegetative apices. Savanna species had a prevalence of lipid secretion in habitats with higher luminosity, which had a lower proportion of damaged apices. In contrast, forest species occurred in habitats with lower luminosity and had a higher proportion of damaged
\end{abstract}

Communicated by: Beverley Glover

Silvia Rodrigues Machado

smachado@ibb.unesp.br

1 Programa de Pós-Graduação em Ciências Biológicas (Botânica), UNESP_Univ Estadual Paulista, Caixa Postal 510, Botucatu, SP 18618-970, Brazil

2 Instituto de Biociências, Departamento de Botânica, USP_Universidade de São Paulo, Rua do Matão, 277, São Paulo, SP 05508-090, Brazil

3 Instituto de Biociências, Departamento de Botânica, UNESP, Univ Estadual Paulista, CP 510, Botucatu, SP 18618-970, Brazil apices, in general with the absence of lipids in the colleters. These results highlight that colleters with similar morphology clearly differed in secretions among species, especially between species from savanna and forest, in which the colleters appear potentially associated with protection against irradiation in savanna, but not in the forest environment.

Keywords Apical meristems · Colleters · Glands · Histochemistry $\cdot$ Microclimate $\cdot$ Phenology $\cdot$ Secretion . Shoot apex

\section{Introduction}

Rubiaceae is the fourth largest family of angiosperms and shows a cosmopolitan distribution, with approximately half of its species occurring in the neotropics (Delprete and Jardim 2012). This family is especially diverse and well represented in the Brazilian savanna and tropical forests (Souza and Lorenzi 2005). The presence of interpetiolar stipules with colleters is one of the most important vegetative characteristics of the family Rubiaceae, which distinguishes it from most other families (Robbrecht 1988).

Colleters are secretory structures characterized by the production of mucilage or a mucilage-resin mixture (Fahn 1979) and are present on the adaxial surface of vegetative and reproductive organs, protecting meristems and young structures against desiccation (Kronestedt-Robards and Robards 1991), herbivores, and pathogens (Thomas 1991). Anatomically, colleters are described as emergences comprising a central, multiseriate, vascularized or not, parenchymatous axis covered by palisade-arranged epidermal cells that are specialized in secretion (Fahn 1979). This structural organization characterizes the most common colleter type, designated the standard type (Evert 2006). Based on morphology, the following other 
colleter types are recognized in Rubiaceae: reduced standard, dendroid, intermediate, brush-like, winged, filiform (Lersten 1974; Thomas 1991), and lachrymiform (Miguel et al. 2009). The presence of crystals is common in colleters and represents a taxonomically relevant characteristic (Evert 2006).

The shoot apex is essential for plant building and its damage is considered of high cost for plants (Coley and Kursar 1996). Therefore, the apices could be associated with specific morphological and chemical features that would increase their protection or resistance against harmful agents such as herbivores, desiccation, and solar radiation. In this case, the presence of colleters would be a potential character of protection to the apex of the plants. Colleters differentiate early in the shoot apices and are active in secretion during leaf development (Thomas 1991); however, there is no clear evidence of a relationship between their presence and accurate protection to apex in the budding stage of plants exposed to different environmental conditions. In addition, there are no data on the proportion of damage to the apex and the secretion characteristics or the environment in which the plants occur. These knowledge gaps reinforce the need for integrative studies that associate the morphological type of colleters and their variations, as well as the nature of the secretion with the environmental type where the species occur. At present, research applying this approach is scarce, and the studies conducted by Klein et al. (2004) and Vitarelli and Santos (2009), who investigated the variation in secretions among species of the same genus and between environments, respectively, are noteworthy.
In this study, we characterized the morphotypes and histochemistry of stipular colleters found in 17 Rubiaceae species distributed in two vegetation types with contrasting characteristics, savanna (continuous herbaceous and sparse woody typically named cerrado sensu stricto) and seasonal semideciduous forest. In savanna, Rubiaceae species occur in opened physiognomies (associated with dystrophic soils) and are exposed to the intense incidence of light that generates a drier and hotter microclimate with higher radiation (Coutinho 1978, 2002) when compared with the understory of the adjacent seasonal semi-deciduous forest (commonly associated with mesotrophic and eutrophic soils) (Scariot and Sevilha 2005), which is the stratum that harbors the Rubiaceae species. Thus, we assessed whether colleters of the same morphotype differ regarding the chemical nature of the secretions when comparing species from forest and savanna. Finally, we tested if there is an association among the proportion of damaged apices, chemical compounds of the colleters' secretion, and type of vegetation and microclimate around each individual of Rubiaceae sampled in the field.

\section{Materials and methods}

\section{Species selection and study area}

For the present study, based on field expeditions and herbarium collections, we selected 17 Rubiaceae species varying from herbs, shrubs, and trees (Table 1): nine species growing

Table 1 List of the studied subfamilies and species of Rubiaceae and their respective habits, vegetation types (forest and savanna), and record numbers in the BOTU herbarium in central-western São Paulo state, Brazil

\begin{tabular}{|c|c|c|c|c|}
\hline Subfamily & Species & Habit & Vegetation type & BOTU record \\
\hline \multirow[t]{4}{*}{ Cinchonoideae } & Coccocypselum lanceolatum (Ruiz \& Pav.) Pers. & Herb & Savanna & 28,502 \\
\hline & Guettarda viburnoides Cham. \& Schltdl. & Tree & Savanna & 28,482 \\
\hline & Warzewiczia sp. & Shr & Forest & 28,513 \\
\hline & Cordiera concolor (Cham.) Kuntze & Shr & Forest & 28,483 \\
\hline \multirow[t]{5}{*}{ Ixoroideae } & Cordiera sessilis (Vell.) Kuntze & Shr & Savanna & 28,505 \\
\hline & Ixora gardneriana Benth. & Tree & Forest & 28,488 \\
\hline & Ixora heterodoxa Müll. Arg. & Tree & Forest & 28,492 \\
\hline & Tocoyena formosa (Cham. \& Schltdl.) K. Schum. & Tree & Savanna & 28,506 \\
\hline & Coussarea hydrangeifolia (Benth.) Benth. \& Hook.f. ex Müll.Arg. & Tree & Savanna & 28,499 \\
\hline \multirow[t]{8}{*}{ Rubioideae } & Palicourea rigida Kunth. & Shr & Savanna & 28,484 \\
\hline & Palicourea sp. & Shr & Savanna & 28,514 \\
\hline & Psychotria hoffmannseggiana (Willd. ex Schult.) Müll. Arg. & Shr & Forest & 28,477 \\
\hline & Palicourea marcgravii (A.St.-Hil.) Spreng. & Shr & Forest & 28,501 \\
\hline & Psychotria sp. & Shr & Savanna & 28,512 \\
\hline & Randia sp. & Shr & Forest & 28,511 \\
\hline & Richardia grandiflora (Cham. \& Schltdl.) Steud. & Herb & Forest & 28,476 \\
\hline & Simira corumbensis (Standl.) Steyerm. & Tree & Forest & 28,490 \\
\hline
\end{tabular}

herb herbs, shr shrubs, tree trees 
in the understory of a seasonal semi-deciduous tropical forest and eight species growing in cerrado sensu stricto physiognomies, characterized by a continuous herbaceous and a sparse woody strata (savanna formations), all located in centralwestern São Paulo state, Brazil ( $48^{\circ} 20^{\prime}$ to $48^{\circ} 50^{\prime} \mathrm{W} ; 22^{\circ}$ $40^{\prime}$ to $\left.23^{\circ} 05^{\prime} \mathrm{S}\right)$. The south marginal areas of the cerrado domain and the seasonal semi-deciduous forest are both characterized by marked climatic seasonality. The selected species are unique to each environment as shown in Table 1.

The climate was characterized as Cfa hot climate with rains in the summer and drought in the winter, with average temperature in the hottest month above $22{ }^{\circ} \mathrm{C}$, with small hydric deficiency in April, July, and August (Cunha and Martins 2009). Data of monthly average temperature and monthly accumulated rainfall were obtained from Estação de Radiometria Solar de Botucatu, Faculdade de Ciências Agrárias, UNESP (48 $27^{\prime} \mathrm{W} ; 22^{\circ} 54^{\prime} \mathrm{S}, 786 \mathrm{~m}$ altitude) to prepare a climate diagram (Fig. 1) according to Walter and Lieth (1967).

For each study species, five individuals located in the same area were identified with numbered labels and monitored monthly from May 2011 to April 2012 ( $n=85$ plants, distributed in five study areas).

Voucher specimens were deposited in the Herbarium BOTU of the Department of Botany, Botucatu, Universidade Estadual Paulista (UNESP), SP, Brazil (Table 1).

\section{Colleters' distribution, morphology, and histochemistry}

We collected and dissected vegetative apex samples from the studied species during the budding period to evaluate the distribution, number, size, and morphology of the stipule colleters ( $n=5$ per species). We analyzed three stipules per



Fig. 1 Climate diagram for Botucatu region, central-western São Paulo state, Brazil. Dotted area corresponds to dry period (May-September), stripes and black areas correspond to wet period (October-April) species under a stereoscopic microscope to count all the colleters on the stipule's adaxial surface and to measure their sizes using a system with image capture and software for image processing.

We processed stipule samples ( $n=5$ plants) for scanning electron microscopy (SEM) analyses. For this purpose, samples of the material were fixed in $2.5 \%$ glutaraldehyde in $0.1 \mathrm{M}$ phosphate buffer, $\mathrm{pH} 7.3$, for $24 \mathrm{~h}$ then post-fixed in $1 \%$ osmium tetroxide in $0.1 \mathrm{M}$ phosphate buffer, $\mathrm{pH} 7.3$, for $1 \mathrm{~h}$, dehydrated in an ascending ethanol series, critical point dried using liquid $\mathrm{CO}_{2}$, mounted on aluminum stubs, and gold sputtered (Robards 1978). The material was observed and documented using a FEI Quanta scanning electron microscope at $20 \mathrm{kV}$.

For general histology of the colleters, stipule samples $(n=5$ plants) were fixed in Karnovsky solution (4\% paraformaldehyde; $1 \%$ glutaraldehyde in $0.1 \mathrm{M}$ phosphate buffer, $\mathrm{pH} 7.2$; 0.2 M phosphate buffer, pH 7.2) for 24 h (Karnovsky 1965). We kept the samples fixed in $70 \%$ tertiary butyl alcohol for 7 days then dehydrated them in an ascending butyl series, transferred them to Histo-Clear ${ }^{\circledR}$, and embedded them in Paraplast ${ }^{\circledR}$ (Johansen 1940). Next, we cut 8- to 10- $\mu$ m-thick sections using a semi-automatic rotary microtome and stained the sections with Astra blue and safranin.

We prepared permanent slides using Entelan ${ }^{\circledR}$ synthetic resin and then viewed and photographed them under a microscope coupled to a digital camera. We measured the length and width of the colleters of each studied species in longitudinal sections of the vegetative apex ( $n=5$ per species), using the LAS measuring system, version 3.8.

We used sectioned material for in situ identification of the main chemical classes of compounds present in the colleters. For this purpose, we performed tests using the following histochemical stains: Sudan IV for total lipids (Pearse 1980), the periodic acid/Schiff reagent (PAS) for neutral polysaccharides (Cortelazzo 1992), ruthenium red for acid polysaccharides (Jensen 1962), ferric chloride for phenolic compounds (Johansen 1940), mercuric bromophenol blue solution for proteins (Mazia et al. 1953), tannic acid/iron chloride III for mucilages (Pizzolato and Lillie 1973), the Dragendorff reagent for alkaloids (Svendsen and Verpoorte 1983), and cupric acetate for resin (Johansen 1940).

\section{Phenology}

We evaluated the phenology, according to Fournier (1974), focusing on the budding phase. We investigated the presence and aspect of exudates covering the shoot apices by the naked eye.

\section{Microclimate}

Temperature, relative humidity $(\mathrm{RH})$, and luminosity were measured using portable thermometer, hygrometer, and 
luximeter, respectively. Data were collected next to the branches of each specimen, monthly for a year.

\section{Proportion of damaged apices}

For herbs, shrubs, and small trees (Table 1) having less than 40 branches, all the vegetative apices were evaluated in loco. For bigger trees, Coussarea hydrangeifolia, Guettarda viburnoides, and Simira corumbensis, ten apices in each cardinal point of the plant were evaluated, totaling 40 apices sampled per tree. All the labeled plants were investigated for the presence of apex damage using a portable magnifying glass. The evaluations were performed in the dry (August/ September) and wet (January/February) periods.

We considered 'damaged apices' as those having injury, necrosis, or total loss of tissue, regardless of their causes (e.g., herbivores, desiccation, or ablation). The mean proportion of damaged apices in relation to the total number of sampled apices per species ( $n=5$ plants) was calculated in both periods, dry and wet.

\section{Data analysis}

To analyze the temporal distribution of the vegetative apex budding, circular statistics was employed. For this approach, we consider the period of 1 year in a circular scale of measurements (Batschelet 1981; Zar 2010). To adapt the data to the circular scale, we converted the days to the specific angle of the sampling day. For this calculation, the total angles of a circle $\left(360^{\circ}\right)$ was divided by the total number of days of the year (365), obtaining the value of 0.98 for each day of the year. Since our data was not normal, the data variation was described based on the median and quartiles. To determine the intensity of seasonality, we use the length of the vector $(r)$. This parameter is a measure of the data concentration around the mean angle and ranges from 0 (disaggregated data) to 1 (data concentrated in the same direction) (Zar 2010). The distribution of data was verified by Watson test based on the null hypothesis that the data follows the von Mises distribution (normal distribution analogous to the linear data). To investigate the occurrence of seasonality, we employed the Kuiper test based on the null hypothesis that the data presents uniformity, i.e., they are equally distributed around the circle (Jammalamadaka and SenGupta 2001; Zar 2010). The analyses were performed using the computing environment R packages "circular" (Agostinelli and Lund 2011) and "CircStats" (Jammalamadaka and SenGupta 2001).

To compare the differences in the proportions of species with each chemical compound (lipids, resin, phenols, and alkaloids) between the savanna and forest, a binomial proportion test was applied. In order to check for differences in microclimate factors (maximum and minimum $\mathrm{RH}$, maximum and minimum temperature, and maximum and minimum irradiation) around plants, we used analyses of variance (ANOVA, one-way), in which the response variables were each a quantitative descriptor of microclimate (maximum and minimum) and the independent variable was the vegetation type (savanna and forest). We also verified if the variation in the proportion of damaged apices could be explained by the presence of specific chemical compounds, the microclimate, or the vegetation type (forest and savanna). As there was no significant difference in the proportion of damaged apices between the dry and wet periods (paired $t$ test; $t=1.3572$; d.f. $=16 ; p=0.19$ ), the mean value per species, considering both periods, was used as the overall proportion of damaged apices in the subsequent analyses. Therefore, to explain the variation in the overall proportion of damaged apices, we applied the ANOVA one-way and linear regression, depending on the nature of the independent variable considered, if discrete (e.g., vegetation type or chemical compounds) or continuous (e.g., maximum relative humidity). The assumptions of all analyses (normality and homogeneity of variances) were verified through graphical inspection of the distribution of the response variable values (histogram) and residues of each test individually. No transformation was applied to the original data before analysis. All analyses were performed in the computing environment $\mathrm{R}$.

\section{Results}

\section{Colleters' distribution, morphology, and histochemistry}

We found that the examined colleters were associated with four morphological types of stipules: rounded, oval with bifurcate apices, fimbriate, and lanceolate. This information is summarized in Table 2.

Colleters varied regarding their distribution (Figs. 2 and 3a-d) and number (Table 2) on the adaxial surface of the stipules. We observed four patterns of distribution of colleters: colleters distributed across the entire surface of the stipulesCordiera concolor (Fig. 2a), Cordiera sessilis (Fig. 2b), Coccocypselum lanceolatum, and Richardia grandiflora, with a lower density, occurring in the two latter species; colleters located within the concave region of the stipules occupying an area from the base to the apical region, in a triangular arrangement-G. viburnoides (Figs. 2f and 3b), Ixora gardneriana, Ixora heterodoxa (Fig. 2d), Palicourea rigida (Fig. 2e), S. corumbensis, Tocoyena formosa, and Warszewiczia sp.; colleters arranged in one or two longitudinal rowsC. hydrangeifolia, Randia sp. (Fig. 2g), Psychotria hoffmannseggiana, Palicourea marcgravii, Psychotria sp., and Palicourea sp.; and isolated colleters found in the distal region of the stipules in Palicourea sp. (Fig. 3d). The number of colleters per stipule and size (height and width) of colleters 


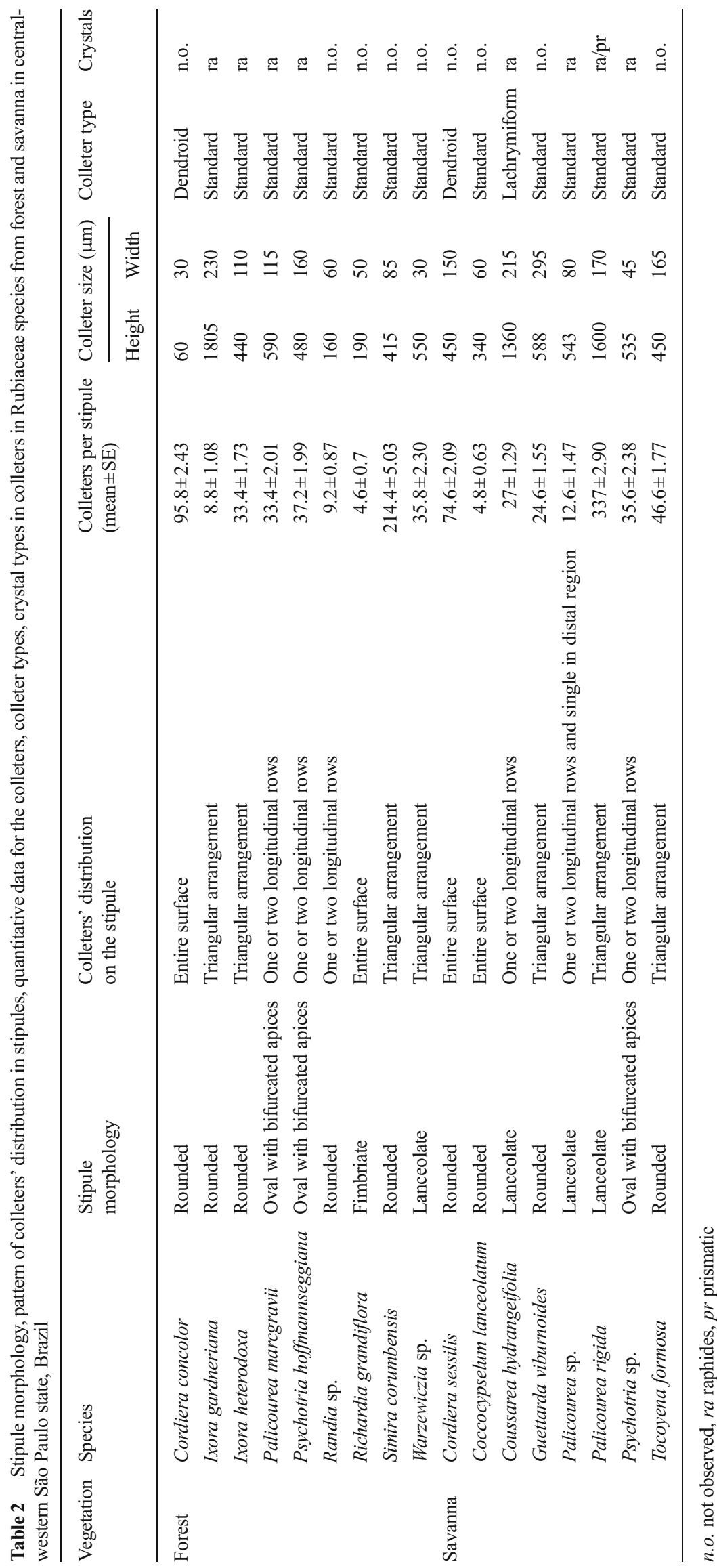




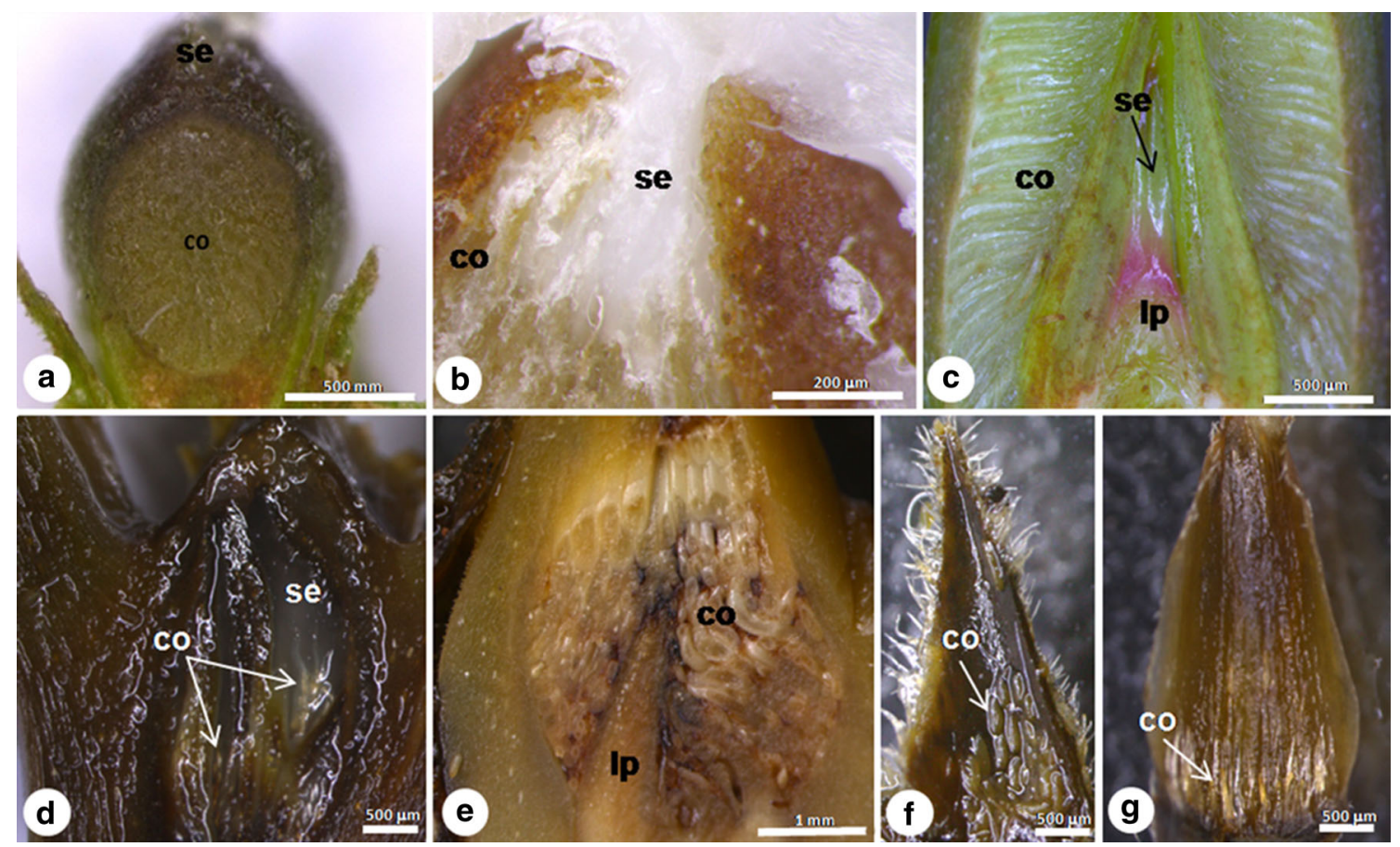

Fig. 2 Exudates and distribution of colleters on the adaxial surface of the stipules in vegetative apices of Rubiaceae species. a-e Longitudinal sections of apices. $\mathbf{f}-\mathbf{g}$ Adaxial surface of stipules. $\mathbf{a}-\mathbf{b}$ Resinous secretions (se) covering the vegetative apices in Cordiera concolor (a) and Cordiera sessilis (b). c Hydrophilic secretion (se) covering the apex and leaf primordium (lp) in Simira corumbensis. d Resinous secretions (se) covering the vegetative apex in Ixora heterodoxa. e Numerous colleters $(\mathrm{co})$ projecting themselves onto other colleters and leaf primordium ( $l p$ ) in Palicourea rigida. f Colleters ( $c o$ ) triangularly arranged in the concave portion of the stipules in Guettarda viburnoides. g Colleters (co) arranged in longitudinal rows in Randia sp. co colleters, se secretion, $l p$ leaf primordium ranged widely among the studied species, independently of the vegetation type (Table 2).

In most Rubiaceae species, colleters were accompanied by non-glandular trichomes (Fig. 3a-c, E). Non-glandular trichomes were scarce in C. concolor (Fig. 3a), C. sessilis, I. gardneriana, I. heterodoxa, P. hoffmannseggiana, Psychotria sp., Randia sp. and abundant in C. lanceolatum, G. viburnoides (Fig. 3b), R. grandiflora, T. formosa (Fig. 3e), and Warszewiczia sp. (Fig. 3c). Non-glandular trichomes were lacking in Palicourea species, C. hydrangeifolia, and S. corumbensis.

The colleter type and the presence and type of crystals were indicated for each examined species (Table 2). Standard colleters occurred in 14 of the 17 studied species (Table 2). Standard colleters exhibited a main body (Fig. 3e) and a constriction at the base (Fig. 3e, f), forming a peduncle. The main body has a smooth surface, which can have grooves on its distal portion (Fig. 3g). Dendroid colleters were recorded in C. concolor and C. sessilis, and lachrymiform colleters were exclusively found in C. hydrangeifolia (Table 2). Calcium oxalate crystals in colleters were observed in $47 \%$ of the studied species (Table 2). Crystals were predominantly of raphide type, occurring in clusters (Fig. 3h, i), except in $P$. rigida that contains both prismatic crystals and raphides (Table 2).
Standard colleters were quite similar in histological organization. The main body has a sharp distinction between the secretory epithelium comprising palisade-arranged epidermal cells, and a central axis formed by axially elongated parenchyma cells (Fig. 4a-d). Standard colleters had considerable variation in height, width, and number of both epithelial cells and central parenchyma cells (Fig. 4a, b, d). The peduncle can have a variable size (Fig. 4a, b, d). Vascularization of the central axis was observed in colleters of $P$. rigida (Fig. 4e).

Lachrymiform colleters had a similar histological organization to standard colleters, being characterized by a pointed apex and a peduncle with a wide base (Fig. 4f).

Dendroid colleters exhibited a central axis comprising axially arranged parenchyma cells surrounded by a secretory epithelium formed by conical, elongated epidermal cells with irregular sizes, only attached at the base (Fig. 4g).

Colleters active in secretion were observed in the vegetative apex during the budding phase in species from both the forest and savanna. These colleters were turgid with a green-yellowish color and exhibited abundant secretions that varied from hyaline to milky, covering the entire vegetative apex (Fig. 2). In the first case, the colleters were initially green and smaller. Colleters inactive in secretion become brown and loose 
Fig. 3 Distribution and morphology of colleters in Rubiaceae species under scanning electron microscope. a Dendroid colleters $(c o)$ between massive non-glandular trichomes $(n t)$ in Cordiera concolor. b-c Standard colleters $(c o)$ between nonglandular trichomes $(n t)$ in Guettarda viburnoides (b) and Warszewiczia sp. (c). d Single standard colleter $(\mathrm{co})$ in the distal region of the stipule's adaxial surface in Palicourea sp. e-g Standard colleters in Tocoyena formosa. e General aspect. f Proximal region of the colleter showing peduncle (arrow). G Grooves in surface (arrowhead) on the distal region of the colleter. $\mathbf{h}-\mathbf{i}$ Standard colleters in Palicourea marcgravii. $\mathbf{h}$ Idioblasts containing raphides in the parenchyma axis. i Detail of the cluster of raphides $(\mathrm{ra})$. co colleter, $n t$ non-glandular trichome, $r a$ raphides
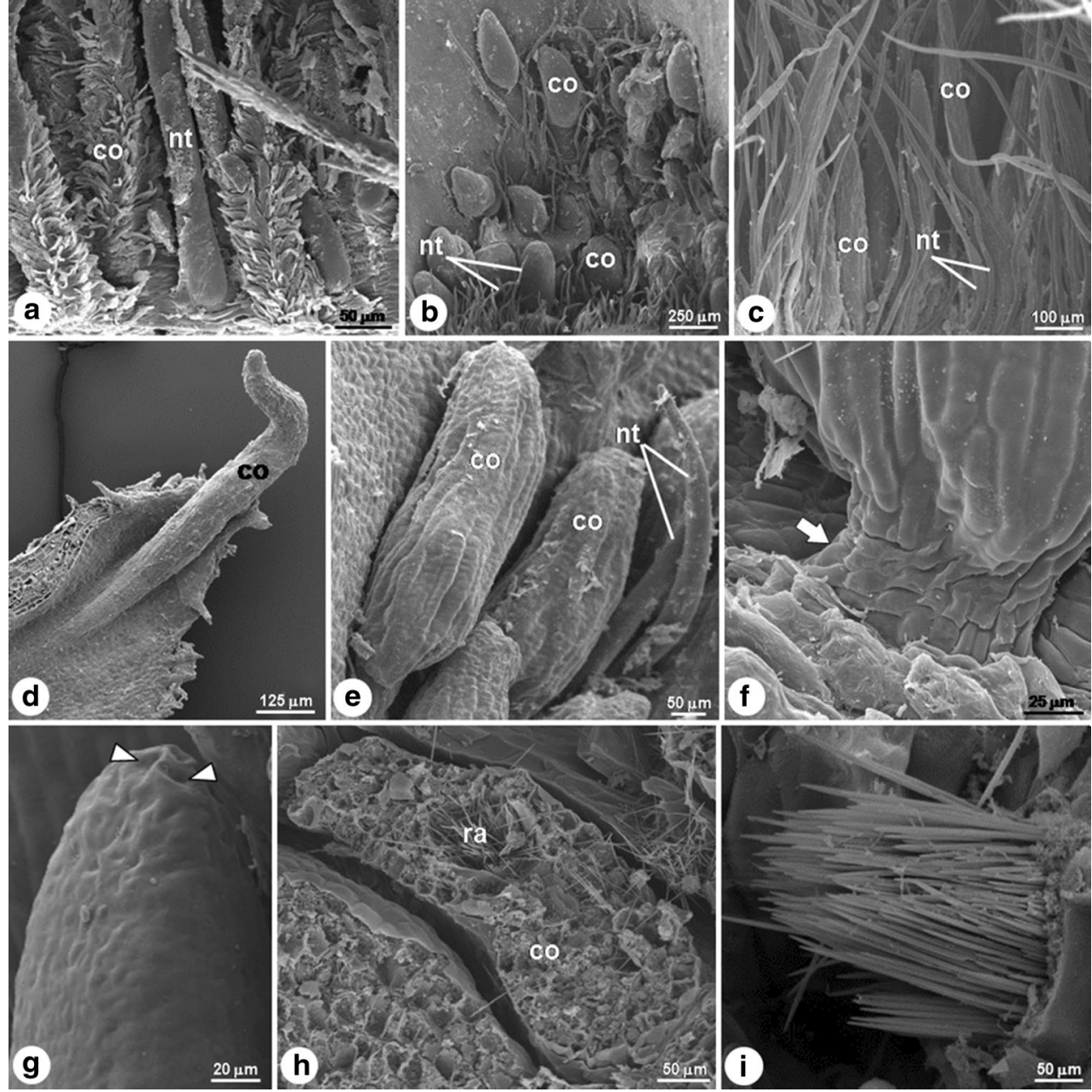

in aspect. In both cases, the changes in the colleters follow the senescence process of the stipules, which may be deciduous or may persist until the development of new apices.

Neutral polysaccharides, proteins, and pectic substances were histochemically detected in the epithelial cells of colleters in all of the studied species (Table 3). Whereas, lipids, alkaloids, phenolic compounds, and resins were detected in the epithelial cells of some species, with a prevalence of lipids in the species from the savanna (Table 3).

\section{Temporal variation in budding and in the presence of exudates in the vegetative apices}

The studied species showed continuous budding. For the forest species, the distribution of this event was more homogeneous with a peak around $20 \%$ of budding in August (dry season) (Fig. 5a) and two peaks of greater intensity in the savanna, with approximately
$40 \%$ of budding concentrated in the months of October and February (rainy season) (Fig. 5b).

Analyzing all species, regardless of the type of vegetation, $64 \%$ had a budding peak at the end of the rainy season (February, March, and April) and at the beginning of the dry season (May) (Table 4). During the dry period, budding peaks were recorded in four species of forest $C$. concolor, I. heterodoxa, $R$. grandiflora, and Warzewiczia spp. and two species of savanna C. lanceolatum and T. formosa (Table 4).

In all Rubiaceae species, secretion covering the vegetative apices was recorded during the budding period. The exudate ranged from translucent to off-white if composed by mucilage or resin, respectively. At the initial stages of leaf development, an exudate accumulation was detected inside the chamber formed by the stipules involving the vegetative apex. With the separation of the stipules, the leaf primordia and young leaves were exposed and the exudate covering all the new leaf created a translucent film on both surfaces. After the complete leaf expansion, the exudate remained as isolated patches throughout the blade. 
Fig. 4 Colleter types in Rubiaceae species. a-e Standard colleters. a Tocoyena formosa, observe the central axis $(\mathrm{ca})$ surrounded by epidermal cells (ep), peduncle (arrow), and colleters' exudates (asterisk). b-c Ixora heterodoxa. d Guettarda viburnoides. e Palicourea rigida, note vascular elements (arrowhead) in central axis (ca). $\mathbf{f}$ Lachrymiform colleter in Coussarea hydrangeifolia, note the pointed apex and a peduncle with a wide base. $\mathbf{g}$ Dendroid colleters in Cordiera concolor, observe that the epidermal cells (ep) showed irregular sizes and they were attached only at the base. $\mathbf{a}, \mathbf{b}, \mathbf{d}-\mathbf{g}$ Longitudinal sections. c Transverse section. $c a$ central axis, $e p$ epidermal cells
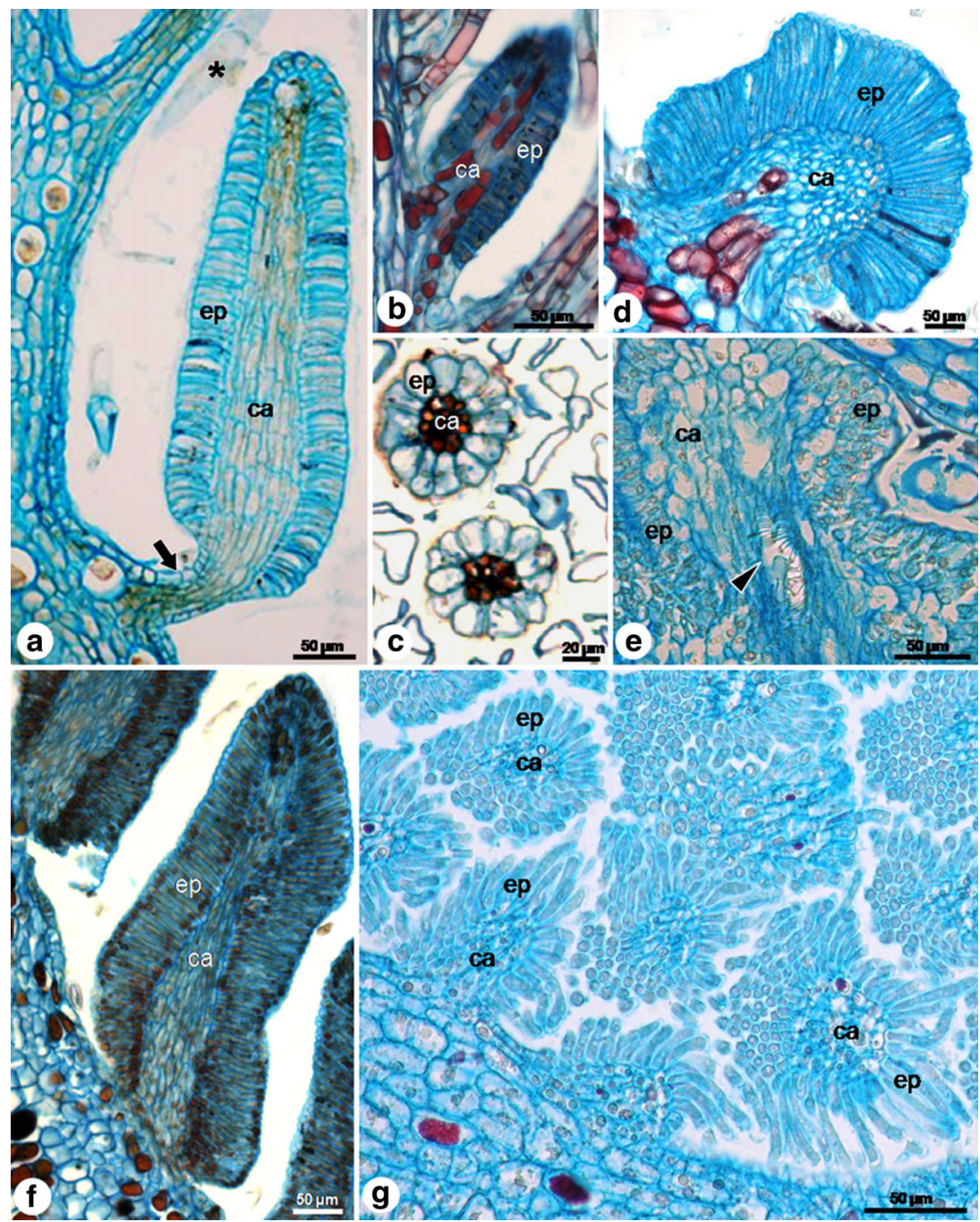

\section{Microclimate around the studied plants in forest and savanna}

In general, the relative humidity maximum $\mathrm{RH}\left(\mathrm{F}_{(1,15)}=\right.$ $0.03 ; p=0.86)$ and minimum $\mathrm{RH}\left(\mathrm{F}_{(1,15)}=0.2 ; p=0.68\right)$ around the studied plants did not differ between the two vegetation types (Fig. 6a). The maximum temperature did not differ between vegetation types $\left(\mathrm{F}_{(1,15)}=0.3\right.$; $p=0.59)$. The minimum temperature $\left(\mathrm{F}_{(1,15)}=7.5 ; p=\right.$ $0.01)$ and the temperature amplitude $\left(\mathrm{F}_{(1,15)}=6.5 ; p=\right.$ 0.02 ) differed significantly between the two vegetation types (Fig. 6b). The temperature amplitude was $6-7{ }^{\circ} \mathrm{C}$ higher in the savanna than in the forest environment (Fig. 6b). The maximum luminosity was the variable that most differed between the two vegetation types $\left(\mathrm{F}_{(1,15)}=41.4 ; p<0.001\right)$, and the savanna showed about $600 \%$ more light than the forest (Fig. 6c). The minimum luminosity (values close to zero in both vegetation types) was on average higher in the savanna $\left(\mathrm{F}_{(1,15)}=\right.$ $4.14 ; p=0.06)$.

\section{Proportion of species with lipids, resins, phenolic compounds, and alkaloids in colleters from forest and savanna}

The proportion of species with colleters containing lipids, resins, alkaloids, and phenolic compounds was variable between forest and savanna species (Fig. 7). Lipids were present almost exclusively in savanna species, differing significantly from the forest ones $\left(\chi_{2}=\right.$ $7.1 ; \mathrm{df}=1, p<0.01$ ), while the proportion of species with other compounds did not differ significantly between the two vegetation types (resin: $\chi 2=0.5 ; \mathrm{df}=1 ; p=0.47$; phenols: $\chi 2=0.8 ; \mathrm{df}=1 ; p=0.36$; alkaloids: $\chi^{2}=0, \mathrm{df}=$ $1, \mathrm{p}=1)$. 
Table 3 Main classes of compounds present in the colleters' secretory epithelium in 17 Rubiaceae species from forest and savanna in central-western São Paulo state, Brazil

\begin{tabular}{|c|c|c|c|c|c|c|c|c|}
\hline Vegetation & Species & Lipids & Alkaloids & Phenolic substances & Resin & Polysaccharides & Proteins & Pectic substances \\
\hline \multirow[t]{9}{*}{ Forest } & Cordiera concolor & + & - & + & + & + & + & + \\
\hline & Ixora gardneriana & - & - & - & + & + & + & + \\
\hline & Ixora heterodoxa & - & - & - & + & + & + & + \\
\hline & Psychotria hoffmannseggiana & - & + & + & - & + & + & + \\
\hline & Palicourea marcgravii & - & + & + & - & + & + & + \\
\hline & Randia sp. & - & + & + & - & + & + & + \\
\hline & Richardia grandiflora & - & + & - & - & + & + & + \\
\hline & Simira corumbensis & - & + & + & - & + & + & + \\
\hline & Warzewiczia sp. & - & - & - & - & + & + & + \\
\hline \multirow[t]{8}{*}{ Savanna } & Cordiera sessilis & + & - & + & + & + & + & + \\
\hline & Coccocypselum lanceolatum & + & - & + & - & + & + & + \\
\hline & Coussarea hydrangeifolia & + & + & + & + & + & + & + \\
\hline & Guettarda viburnoides & + & - & - & + & + & + & + \\
\hline & Palicourea sp. & + & + & + & + & + & + & + \\
\hline & Palicourea rigida & + & - & + & + & + & + & + \\
\hline & Psychotria sp. & - & + & + & - & + & + & + \\
\hline & Tocoyena formosa & + & + & + & - & + & + & + \\
\hline
\end{tabular}

+ denotes presence; - denotes absence

\section{Relationship among the proportion of damaged apices and the vegetation type, microclimate variables around plants, and colleter secretion}

The proportion of damaged apices ranged from 0 to approximately $50 \%$ among the Rubiaceae species. The proportion of damaged apices showed a positive correlation with maximum RH (Fig. 8a; $\mathrm{F}_{(1,15)}=10.9, p=0.005 ; R^{2}=0.38$ ), regardless of the vegetation type. The other microclimate variables measured around plants did not explain the variation of damaged apices, including the minimum $\mathrm{RH}\left(\mathrm{F}_{(1,15)}=0.03, p=0.86\right.$;
$\left.R^{2}=0.06\right)$, maximum $\left(\mathrm{F}_{(1,15)}=2.52, p=0.13 ; R^{2}=0.09\right)$ and minimum $\left(\mathrm{F}_{(1,15)}=0.36, p=0.56 ; R^{2}=0.04\right)$ temperatures, and maximum $\left(\mathrm{F}_{(1,15)}=0.13, p=0.72 ; R^{2}=0.06\right)$ and minimum $\left(\mathrm{F}_{(1,15)}=0.40, p=0.53 ; R^{2}=0.04\right)$ luminosity. This analysis was repeated excluding the outlier detected in the upper right corner of the graph, and the result remained the same (continuous line with the complete dataset and dashed line without the outlier-Fig. 8a). On average, forest species had a higher proportion of damaged apices as compared to the savanna species (Fig. 8b; $\mathrm{f}_{(1,14)}=4.7, p=0.047$ ). Additionally, species that have lipids in colleters had, on average, a lower
Fig. 5 Circular histogram of the monthly relative frequency of budding Rubiaceae species in a forest and $\mathbf{b}$ savanna vegetation located in central-western São Paulo state, Brazil
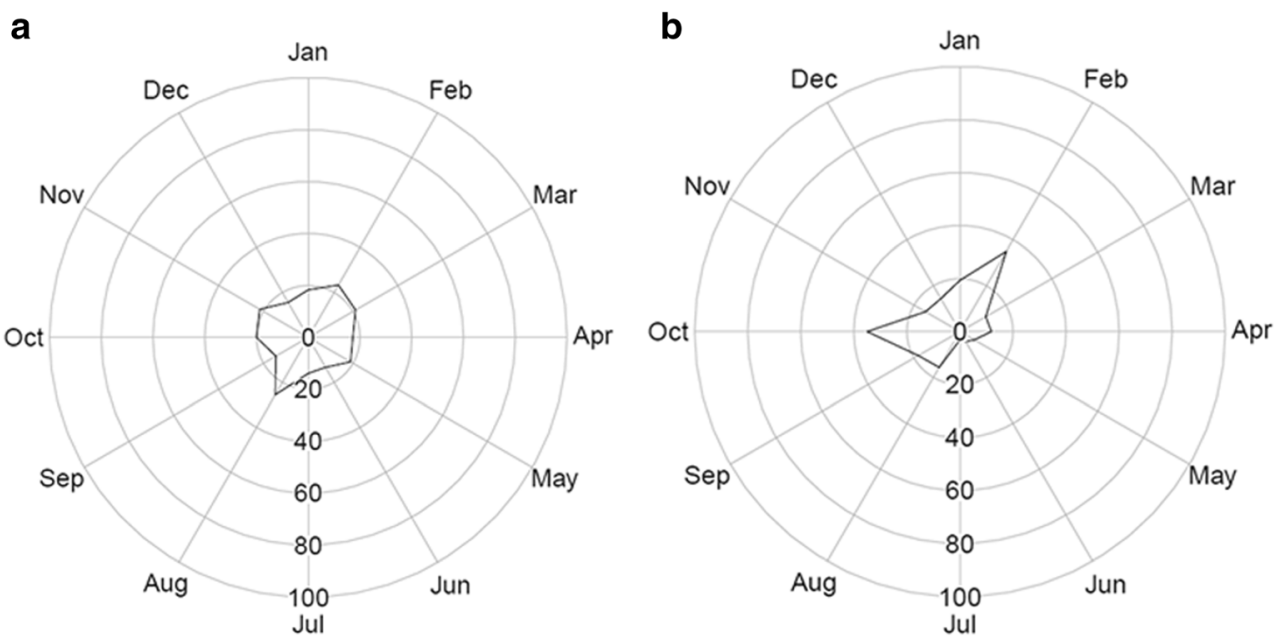
Table 4 Descriptive circular statistics for budding period in Rubiaceae species from forest and savanna in central-western São Paulo state, Brazil

\begin{tabular}{|c|c|c|c|c|c|}
\hline Species & Median $\left(1^{\circ}\right.$ and $3^{\circ}$ quartiles $)$ & Month of budding peak & $r$ & Kuiper test & Watson test \\
\hline \multicolumn{6}{|l|}{ Forest } \\
\hline Cordiera concolor & $\begin{array}{c}337.52 \\
(278.70-19.60)\end{array}$ & September & 0.634 & 101.40 & 14.624 \\
\hline Ixora gardneriana & $\begin{array}{c}139 \\
(78.38-309.13)\end{array}$ & May & 0.281 & 35.58 & 0.575 \\
\hline Ixora heterodoxa & $\begin{array}{c}168.56 \\
(78.38-248.33)\end{array}$ & August & 0.302 & 77.74 & 1.207 \\
\hline Palicourea marcgravii & $\begin{array}{c}49.98 \\
(367.90-78.38)\end{array}$ & February-April & 0.479 & 63.12 & 0.907 \\
\hline Psychotria hoffmannseggiana & $\begin{array}{c}309.13 \\
(309.13-337.52)\end{array}$ & October & 0.758 & 83.97 & 29.629 \\
\hline Randia sp. & $\begin{array}{c}93.56 \\
(49.98-139)\end{array}$ & February-May & 0.511 & 82.31 & 0.673 \\
\hline Richardia grandiflora & $\begin{array}{c}248.33 \\
(139-248.33)\end{array}$ & May, August & 0.537 & 4.64 & 1.747 \\
\hline Simira corumbensis & $\begin{array}{c}49 \\
(19.60-78.38)\end{array}$ & Jan, March & 0.871 & 39.16 & 0.584 \\
\hline Warzewiczia sp. & $\begin{array}{c}278.70 \\
(218.94-367.90)\end{array}$ & August, November & 0.226 & 55.64 & 0.557 \\
\hline \multicolumn{6}{|l|}{ Savanna } \\
\hline Cordiera sessilis & $\begin{array}{c}278.70 \\
(168.56-309.13)\end{array}$ & February, May, October & 0.117 & 66.85 & 15.256 \\
\hline Coccocypselum lanceolatum & $\begin{array}{c}248.33 \\
(108.80-248.33)\end{array}$ & August & 0.191 & 61.08 & 18.094 \\
\hline Coussarea hydrangeifolia & $\begin{array}{c}399.60 \\
(19.60-49.98)\end{array}$ & January-February & 0.920 & 75.07 & 13.639 \\
\hline Guettarda viburnoides & $\begin{array}{c}337.52 \\
(309.13-19.6)\end{array}$ & October & 0.508 & 76.57 & 14.793 \\
\hline Palicourea rigida & $\begin{array}{c}323.31 \\
(309.13-367.90)\end{array}$ & October & 0.700 & 82.37 & 0.775 \\
\hline Palicourea sp. & $\begin{array}{c}49.98 \\
(367.90-78.38)\end{array}$ & February-March & 0.554 & 74.48 & 0.829 \\
\hline Psychotria sp. & $\begin{array}{c}19.60 \\
(309.13-49.98)\end{array}$ & February & 0.353 & 57.65 & 1.234 \\
\hline Tocoyena formosa & $\begin{array}{c}49.98 \\
(278.70-49.98)\end{array}$ & February, September & 0.483 & 43.65 & 11.631 \\
\hline
\end{tabular}

All tests were significant $(p<0.05)$

proportion of damaged apices (Fig. $8 \mathrm{c} ; \mathrm{f}_{(1,14)}=6.6 ; p=0.02$ ). The species with other compounds in the colleters showed no significant differences in the proportion of damaged apices (Fig. 8d-f; resins: $\mathrm{F}_{(1,14)}=3.5, p=0.08$; phenolic: $\mathrm{F}_{(1,14)}=$ $0.35 ; p=0.56$; alkaloids: $\left.\mathrm{F}_{(1,14)}=0.91 ; p=0.35\right)$.

\section{Discussion}

In this study, we compared 17 Rubiaceae species located in the neotropical savanna and forest focusing on colleters' secretions, using an integrative approach combining morphological, histochemical, and ecological evidences of the colleters' function. Firstly, we detailed the morphological patterns of colleters, its arrangement (descriptive and quantitative variation of colleters), and the histochemistry with focus on the nature of secretion (hydrophilic, lipophilic, or mixed). We also discussed the temporal variation of budding and exudates on vegetative apices and its implications on the protective role of stipular colleters between the savanna and forest species. Additionally, we explored the differences between the microclimate around plants from savanna and forest, the proportion of damaged apices in both environments, and its correlation to colleters' secretions.

\section{Morphology and arrangement of colleters in Rubiaceae species}

Among the 17 investigated species, 14 exhibited colleters of standard-type, except for $C$. hydrangeifolia, which had lachrymiform type, and the two species of Cordiera genus that had dendroid colleters. As referred by Lersten (1974, 1975), the standard type is the most commonly found, with the dendroid colleters occurring in few Rubiaceae genera (Lersten 1974). Lachrymiform colleters are rarely described 
Fig. 6 Variation in microclimate variables (maximum and minimum in each graph) nearby Rubiaceae plants in forest and savanna environment. In each graph, the maximum values appeared in gray and minimum values in white. Different letters indicate statistically significant difference between the forest and savanna microclimates $(p \leq 0.05)$ a

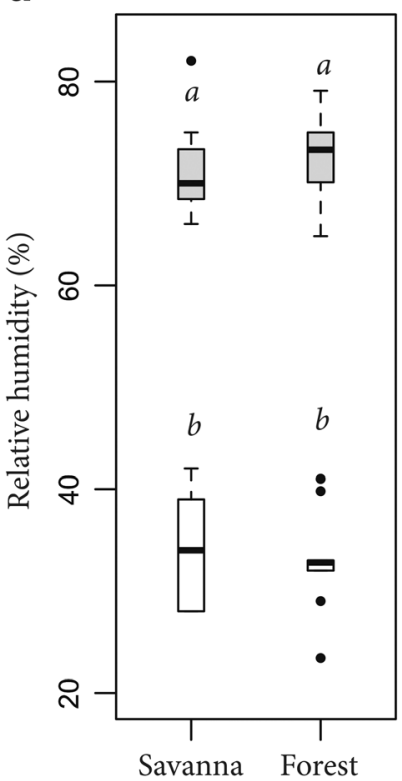

b



C



in Rubiaceae, and this colleter type was referred for the first time in Psychotria nuda (Miguel et al. 2009).

The arrangement of colleters of the studied species is associated with the morphological type of the stipule. Oval stipules with bifurcate apices had colleters arranged in rows, rounded stipules had colleters arranged across the entire surface or triangularly clustered, fimbriate stipules exhibited colleters across the entire surface and lanceolate stipules showed colleters triangularly clustered or arranged in rows. The colleter arrangement is an important character to identify Rubiaceae species (Aiello 1979; Thomas 1991). In agreement with these reports, more recently, Klein et al. (2004) observed interspecific variation in the arrangement of colleters as was observed in Simira genus, with colleters arranged in rows in S. rubra and S. pikia and triangularly arranged in S. glaziovii, showing the importance of this character to distinguish species from the same genus. The presence of non-glandular trichomes distributed among the colleters has been referred as a common trait in Rubiaceae species (Lersten 1974).

Our results showed variation in the average length of colleters ranging from 1805 to $60 \mu \mathrm{m}$, with most species presenting average length of colleters between 590 and $415 \mu \mathrm{m}$, contradicting the hypothesis proposed by Lersten (1974). According to this author, the variation in the size of colleters is associated with the species geographic distribution; the larger colleter sizes was founded in neotropical Rubiaceae species (2600 to $776 \mu \mathrm{m}$ ), with average colleters presenting declines westward through Oceania $(735 \mu \mathrm{m})$, Philippines $(553 \mu \mathrm{m})$, East Indies, and Australia $(480 \mu \mathrm{m})$, Asia $(410 \mu \mathrm{m})$, and Africa $(334 \mu \mathrm{m})$. Furthermore, the size of colleters does not
Fig. 7 Proportion of Rubiaceae species with colleters containing lipids, resins, phenolic compounds, and alkaloids in forest and savanna vegetation in central-western São Paulo state, Brazil. Asterisk indicates statistically significant difference $(p \leq 0.05)$

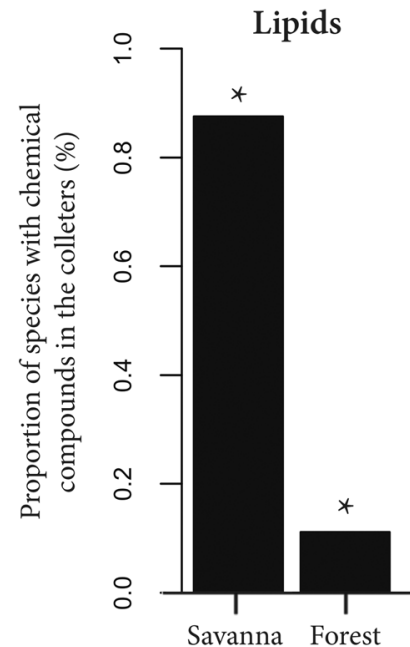

Phenolics

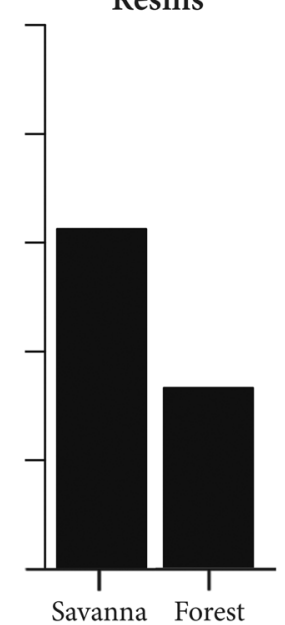

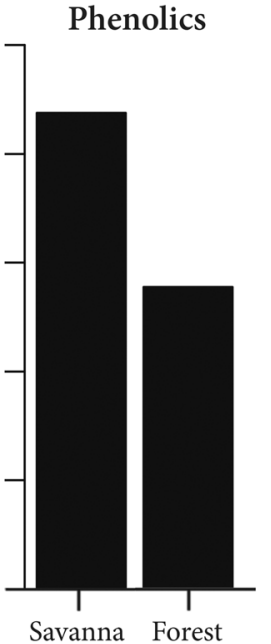

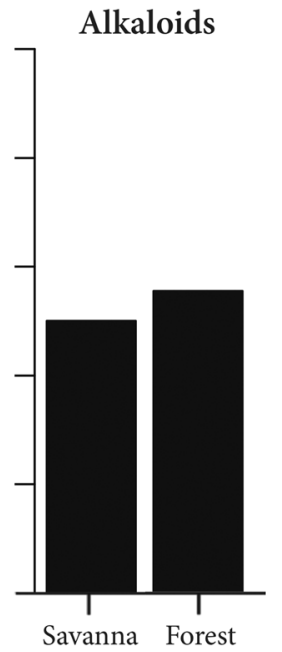


Fig. 8 Variation in the proportion of damaged apices in relation to the relative humidity (a) (without outlier is represented with a dotted line), vegetation type (b), and chemical compounds in colleters (c-f) in Rubiaceae species from forest and savanna vegetation in central-western São Paulo state, Brazil. Different letters indicate statistically significant difference $(p \leq 0.05)$
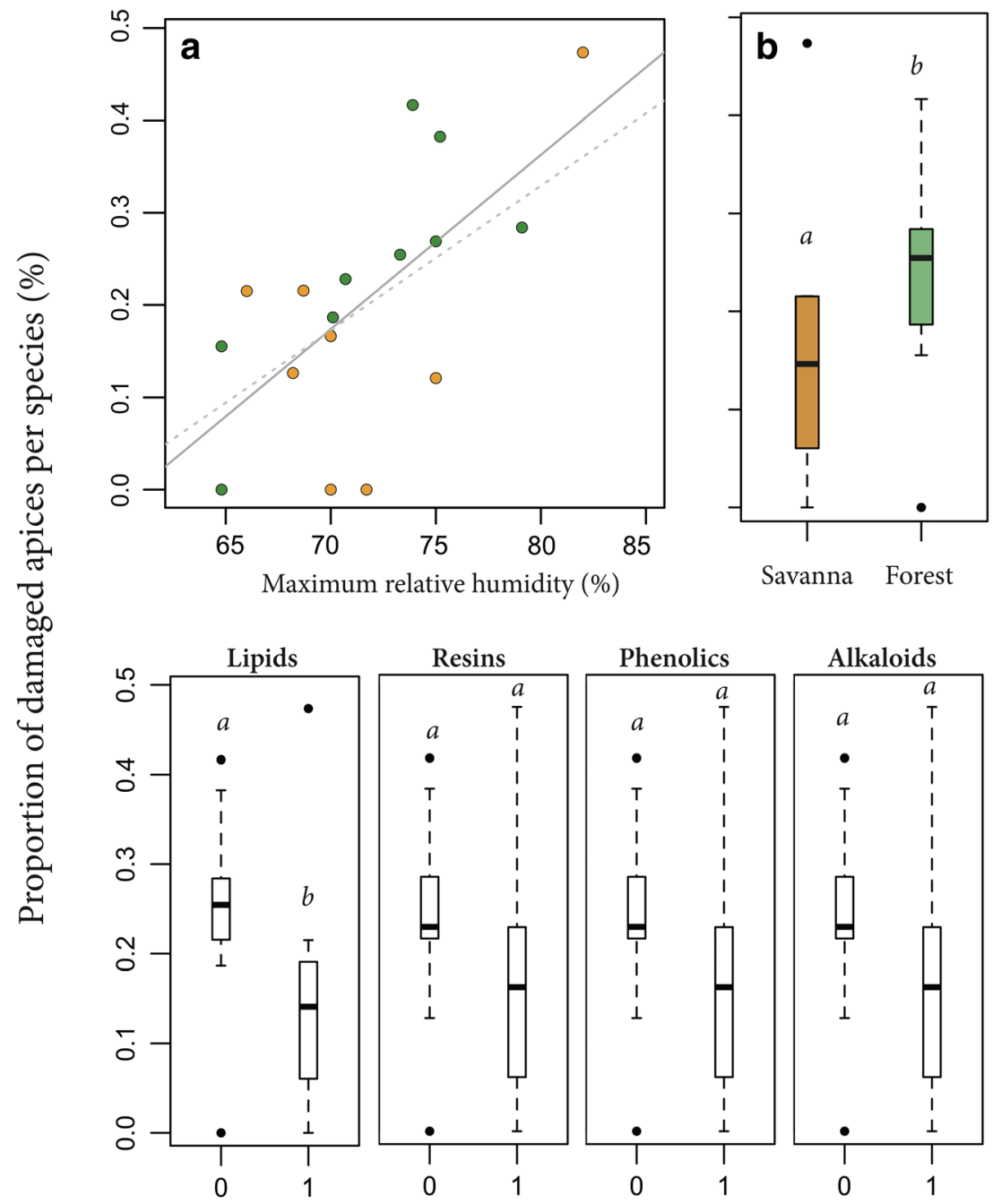

Chemical compounds in the colleters

(Absence $=0$; Presence $=1)$ appear to be associated with the colleters' vascularization as proposed by Carlquist (1969). For example, the colleters of I. gardneriana were the biggest but were not vascularized, being markedly reduced in numbers (around nine per stipule). Whereas, the colleters of $P$. rigida, relatively smaller, but more abundant, were vascularized. We hypothesize that the number of colleters associated with their large size is determinant to the vascularization supply since this sink area requires a greater input of assimilates. These requirements could be provided by vascular tissue connected to the parenchyma cells of the central axis, aiding in supplying precursors to synthesize the secretion compounds, similar to what occurs in some extrafloral nectaries (Fahn 1979; Nicolson et al. 2007).

The calcium oxalate crystals in colleters are one of the most important traits of the Rubioideae subfamily due to the specificity of their shape and location in the colleters (Thomas 1991). The protective role of oxalate crystals against herbivore damage is well known (Franceschi and Nakata 2005), although rarely tested experimentally. In our case, the mechanical barrier that could be caused by the oxalate crystals associated with the chemical composition of colleters' secretions might have a relevant role in the apex protection. This report represents the first record of crystals for the Ixoroideae subfamily.

\section{Temporal variation of budding and of exudate presence in vegetative apices}

Although the budding occurred all year long, there were peaks in forest and savanna. Despite the savanna species present mechanisms related to the root system to avoid restrictions on the growth during dry periods (Pinheiro and Monteiro 2010), the budding peaks occurring during the rainy season indicated that periods of higher water availability are probably 
more favorable to the production of new leaves in savanna species. Budding throughout the year in both environments can be related with the hypothesis that endogenous rhythms can be responsible for the timing of phenological events in seasonal tropical environments (Reich and Borchert 1984), as observed by Wright (1991) in a study of Psychotria species.

Changes in secretory constituents throughout the colleter development have been described (Miguel et al. 2010, Paiva 2012), highlighting the record of the presence of lipids in the mature stages of colleters (Klein et al. 2004). During the budding peaks, the secretion that covers the apices is an additional evidence of the protective role of colleters in this phenophase. It emphasized the potential protective role of colleter secretion during the budding in the savanna species, probably protecting the apices against the high incidence of solar radiation.

\section{Histochemistry and ecological aspects of colleters in savanna and forest species}

Mucilage, consisting of polysaccharides and proteins, was detected in all Rubiaceae species. These secretion components protect apices against desiccation and lubricate the meristems and young developing organs (Fahn 1990; Thomas 1991; Evert 2006; Mayer et al. 2013).

Except for mucilage, we observed differences in the composition of secretions in the colleters, when comparing the species from the forest with those from the savanna. A predominantly hydrophilic secretion was observed in the forest species, where $65 \%$ of the sampled species reacted positively for alkaloids and phenolic substances (not significant relationship in our results). In this environment, a positive reaction for lipids and resin was detected in 10 and $30 \%$ of the species, respectively. In the savanna, positive reactions for lipids and resins were also recorded in approximately 90 and $60 \%$ of the species, respectively. Lipophilic secretions, containing as the main compound lipids (and resins in some species), occurred predominantly in the savanna species (significant relationship was detected between lipids and the vegetation type). Based on the observation of the location of these secretory structures and the lipophilic nature of their secretion, it has been proposed that colleters contribute to reduce water loss due to excessive transpiration of young leaves (Paiva 2012) and can also confer protection of the vegetative apices against the desiccation (Barreiro and Machado 2007) caused by elevated temperatures and pronounced periods of drought and against the high rates of solar radiation. According to Coutinho (2002), these climate conditions are common in the opened physiognomies of the Brazilian cerrado (savanna formations) and the local microclimate measurements around savanna study plants also revealed a similar pattern. In this scenario, the high proportion of Rubiaceae species from savanna showing the apices covered with lipid secretions produced by the colleter (and also mucilage and resin in some species) could be considered as evidence of its advantage, but future experimental studies manipulating this compounds will be necessary to properly assess this issue.

Other compounds detected in the colleters of some Rubiaceae species have been related to the anti-herbivory protection of the vegetative apices, such as alkaloids (Trigo et al. 2012), phenolic substances with organoleptic properties (Harborne et al. 1999), proteins due to entomotoxic properties (Melo and Silva-Filho 2002), and crystals, especially those of calcium oxalate, which have been cited as a type of mechanical defense (Franceschi and Nakata 2005). Although phenolic compounds and alkaloids have been verified in most of forest species and not savanna species, we did not verify a clear association between them and these environments with contrasting characteristics. A similar pattern was described for leaf herbivory by Neves et al. (2010) that reported higher abundance and richness of chewing insect in forest trees than in cerrado. We suppose that the higher proportion of damaged apices in the forest, as compared to the savanna, could be associated to the absence of lipids in the colleters' secretion of most forest species. However, only chemical defenses cannot explain the differences observed in this study. According to Neves et al. (2010), other factors should be considered at the habitat level, as soil quality, leaf sclerophylly, leaf longevity, diversity, and abundance of herbivorous insects, microclimatic environmental conditions, structural complexity, and top-down forces.

Although in general, we found characteristic patterns regarding the composition of secretions for each environment, we hypothesized that the chemical compounds associated with the colleter morphotype appear to be phylogenetically correlated and conserved in some particular groups investigated. We found that species of the same genus occurring in savanna and forest had similar patterns of morphology and histochemistry in contraposition to our general results when comparing these two contrasting environments. For example, both Cordiera species, one from savanna and the other from forest, exhibited dendroid colleters and secretions predominately lipophilic, while both Psychotria species occurring in such environments had standard-type colleters and secretion predominantly hydrophilic. Similar results were reported for other Rubiaceae species. In three species of the genus Simira occurring in the same environment, the standard-type colleters varied regarding their distribution in the stipules and vascularization, but not regarding the composition of secretions (Klein et al. 2004). In Psychotria carthagenensis, individuals occurring in contrasting habitats as tropical rain forests, sandbanks, and rheophytic environments exhibited colleters producing polysaccharide secretion (Vitarelli and Santos 2009). These findings reinforce the idea that the qualitative variation of secretion composition of colleters among Rubiaceae congeners could be a phylogenetically conserved trait, although just 
two species per genus have been sampled. Additionally, we did not characterize the quantitative variation of colleter's secretion in our study (e.g., volume and chemical's concentration among species). This aspect of colleter's secretion could be quite different among congeners as suggested by the variation of the number of colleters per stipule among Psychotria species in our study.

In synthesis, our data showed that there is a clear relationship between the nature of a colleter's secretion, vegetation type, luminosity, and the proportion of damage apex among Rubiaceae species. We verified colleters with a prevalence of lipids in savanna species, which were distributed in environments with higher luminosity and had, on average, a lower proportion of damaged apices. In contrast, a hydrophilic secretion was prevalent in forest species growing in habitats with lower luminosity (less extreme conditions), which had higher proportion of damaged apices. The integration of this approach including data about structure, distribution, and histochemistry of colleters; phenology and microclimate of forest; and savanna environment allows a deeper knowledge on stipular colleters in Rubiaceae species from different tropical ecosystems. It is our expectation that this first view of the role of colleters in contrasting environments stimulates additional ecological and evolutionary studies exploring clearly hypothesis based on the morpho-functional variation of plant traits in a species-rich plant clade as Rubiaceae.

Acknowledgments This article is part of the doctoral thesis of F. Tresmondi funded by the 'Fundação de Amparo à Pesquisa do Estado de São Paulo' (FAPESP 2008/55434-7 and grant 2011/02488-5) and by the 'Conselho Nacional de Desenvolvimento Científico e Tecnológico' (CNPq 473289/2010 and granted to Machado, S.R.). We thank Yve Canaveze for the help in the preparation of figures and text revision, Priscila T. Tunes for language editing, Danilo Silva and Daniella Vinha for suggestion on statistical analysis, and the staff of 'Centro de Microscopia Eletrônica (IBB, UNESP)’ for SEM assistance.

\section{References}

Agostinelli C, Lund U (2011). R package 'circular': Circular Statistics (version 0.4-3). R-project website Available: https://r-forge.rproject.org/projects/circular/. Accessed 2014 Sep 23.

Aiello A (1979) A reexamination of Portlandia (Rubiaceae) and associated taxa. J Arnold Arboretum 60:38-123

Barreiro DP, Machado SR (2007) Coléteres dendroides em Cordiera sessilis (Vell.) K. Schum., uma espécie não-nodulada de Rubiaceae. Rev Bras Bot 30:387-399

Batschelet E (1981) Circular statistics in biology. Academic, New York

Carlquist S (1969) Toward acceptable evolutionary interpretations of floral anatomy. Phytomorphology 19:332-362

Coley PD, Kursar TA (1996) Anti-herbivore defences of young tropical leaves: physiological constrains and ecological tradeoffs. Tropical Forest Plant Ecophysiology (eds SS Mulkey and RL Chazdon), pp 305-336.

Cortelazzo AL (1992) Detecção e quantificação do amido em cotilédones de Canavalia ensiformis e C. gladiata durante o desenvolvimento inicial da planta. Rev Bras Bot 15:157-162
Coutinho LM (1978) O conceito de cerrado. Rev Bras Bot 1(1):17-23

Coutinho LM (2002) O bioma do cerrado. In: Klein AL (ed) Eugen Warming e o cerrado brasileiro: um século depois. São Paulo, Editora da Unesp, pp 77-91

Cunha AR, Martins D (2009) Classificação climática para os municípios de Botucatu e São Manuel-SP. Irriga 14(1):1-11

Delprete PG, Jardim JG (2012) Systematics, taxonomy and floristics of Brazilian Rubiaceae: an overview about the current status and future challenge. Rodriguésia 63:101-128

Evert RF (2006) Esau's plant anatomy, meristems, cells, and tissues of the plant body: their structure, function, and development. 3rd edn. Wiley, New Jersey

Fahn A (1979) Secretory tissues in plants. Academic, London

Fahn A (1990) Plant anatomy. Pergamon, Oxford

Fournier LA (1974) Un método cuantitativo para la medición de características fenológicas en árboles. Turrialba 24:422-423

Franceschi VR, Nakata PA (2005) Calcium oxalate in plants: formation and function. Ann Rev Plant Biol 56:41-71

Harborne JB, Baxter H, Moss GP (1999) Phytochemical dictionary: a handbook of bioactive compounds from plants, 2 nd edn. Taylor and Francis, London

Jammalamadaka SR, SenGupta A (2001) Topics in circular statistics. World Scientific, New York

Jensen WA (1962) Botanical histochemistry: principles and practice. W. H. Freeman and Co., San Francisco

Johansen DA (1940) Plant microtechnique. Paul B. Hoeber, Inc., New York

Karnovsky MJ (1965) A formaldehyde-glutaraldehyde fixative in high osmolality for use in electron microscopy. J Cell Biol 27:137A$138 \mathrm{~A}$

Klein DE, Gomes VM, Silva-Neto SJ, Cunha M (2004) The structure of colleters in several species of Simira (Rubiaceae). Ann Bot 94:733740

Kronestedt-Robards E, Robards A (1991) Exocytosis in gland cells. In: Hawea C, Coleman J, Evans D (eds) Endocytosis, exocytosis and vesicle traffic in plants. Cambridge University Press, Cambridge, pp 199-232

Lersten NR (1974) Morphology and distribution of colleters and crystals in relation to the taxonomy and bacterial leaf nodules symbiosis of Psychotria (Rubiaceae). Am J Bot 61(9):973-981

Lersten NR (1975) Colleter types in Rubiaceae, especially in relation to the bacterial leaf nodule symbiosis. Bot J Lin Soc 71:311-319

Mayer JMS, Carmello-Guerreiro SM, Mazzafera P (2013) A functional role for the colleters of coffee flowers. Ann Bot 5: plt029. doi:10. 1093/aobpla/plt029.

Mazia D, Brewer PA, Alfert M (1953) The cytochemical staining and measurement of protein with mercuric bromophenol blue. The Biol Bull 104:57-67

Melo MO, Silva-Filho MC (2002) Plant-insect interaction: an evolutionary arms race between two distinct defense mechanisms. Braz J Plant Physiol 14:71-81

Miguel EC, Moraes DG, Da Cunha M (2009) Stipular colleters in Psychotria nuda (Cham. e Schltdl.) Wawra (Rubiaceae): micromorphology, anatomy and cristals microanalysis. Acta Bot Bras 23: 1034-1039

Miguel EC, Klein DE, Oliveira MA, Cunha M (2010) Ultrastructure of secretory and senescence phase in colleters of Bathysa gymnocarpa and B. stipulate (Rubiaceae). Rev Bras Bot 33:425-436

Neves FS, Araújo LS, Espírito-Santo MM, Fagundes M, Fernandes GW, Sanchez-Azofeifa GA, Quesada M (2010) Canopy herbivory and insect herbivore diversity in a dry forest-savanna transition in Brazil. Biotropica 42(1):112-118

Nicolson SW, Nepi M, Pacini W (2007) Nectaries and nectar. Springer, Dordrecht, The Netherlands 
Paiva EAS (2012) Colleters in Cariniana estrellensis (Lecythidaceae): structure, secretion and evidences for young leaf protection. J Torrey Bot Soc 139:1-8

Pearse AGE (1980) Histochemistry, theoretical and applied: preparative and optical technology. 4th ed. Churchill Livingston, Edinburgh

Pinheiro MHO, Monteiro R (2010) Contribution to the discussions on the origin of the cerrado biome: Brazilian savanna. Braz J Biol 70:95-102

Pizzolato TD, Lillie RD (1973) Mayer's tannicacid-ferric chloride stain for mucins. The Journal of Histochemistry and Cytochemistry 21:56-64

Reich PB, Borchert R (1984) Water stress and tree phenology in a tropical dry forest in the lowlands of Costa Rica. J Ecol 72:61-74

Robards AW (1978) An introduction to techniques for scanning electron microscopy of plant cells. In: Hall JL (ed) Electron microscopy and cytochemistry of plant cells. Elsevier, New York, pp 343-403

Robbrecht E (1988) Tropical woody Rubiaceae. Characteristic features and progressions. Contributions to a new subfamilial classification. Opera Botanica Belgica 1:1-271

Scariot A, Sevilha AC (2005) Biodiversidade, estrutura e conservação de florestas estacionais deciduais no Cerrado. In: A Scariot et al. (eds) Cerrado: ecologia, biodiversidade e conservação. Brasília, DF: Ministério do Meio Ambiente, pp 121-139
Souza VC, Lorenzi H (2005) Botânica sistemática: guia ilustrado para identificação das famílias de Angiospermas da flora brasileira, baseado em APG II. Instituto Plantarum, Nova Odessa

Svendsen AB, Verpoorte R (1983) Cromatography of alkaloids. Elsevier Scientific, New York

Thomas V (1991) Structural, functional and phylogenetic aspects of the colleters. Ann Bot 68:287-305

Trigo JR, Pareja M, Massuda KF (2012) O papel das substâncias químicas nas interações entre plantas e insetos herbívoros. In: DelClaro K, Torezan-Silingardi HM (eds) Ecologia das interações plantas-animais: uma abordagem ecológico-evolutivo. Technical Books Editora, Rio de Janeiro, pp 67-88

Vitarelli NC, Santos M (2009) Anatomia de estípulas e coléteres de Psychotria cartagenensis Jacq. (Rubiaceae). Acta Bot Bras 23: 923-928

Walter H, Lieth H (1967) Klimadiagramamm-Weltatlos. Pusl. Gustav Fischer, Jena

Wright SJ (1991) Seasonal drought and the phenology of understory shrubs in a tropical moist forest. Ecology 72:1643-1657

Zar JH (2010) Biostatistical analysis. 5th edn. Prentice Hill. 